\title{
Inactivation of $E$. coli and $B$. subtilis spores in ozonized cassava starch
}

\author{
Emanuele Oliveira Cerqueira AMORIM ${ }^{1}$, Alline Artigiani Lima TRIBST ${ }^{1}$, \\ Pedro Esteves Duarte AUGUSTO ${ }^{1,2}$, Marcelo CRISTIANINI ${ }^{1 *}$
}

\begin{abstract}
In the present study, the efficacy of ozone inactivation of B. subtilis spores and E. coli in cassava starch was evaluated. Cassava starch with 18 and 30\% moisture content was processed with ozone at concentrations of 40-118 ppm and exposure times of 15-120 minutes. The processing at $113 \mathrm{ppm} / 120$ minutes (maximum exposure level to ozone evaluated) at $18 \%$ of moisture content did not cause significant reduction of $B$. subtilis spores and caused the reduction of only 2 decimal of $E$. coli. On the other hand, when the ozonation process was carried out for 120 minutes at 30\% of moisture content, 3.6 decimal reduction of B. subtilis was achieved at $40 \mathrm{ppm}$ of ozone and total B. subtilis load reduction ( $>5 \log$ cycles) was observed at $118 \mathrm{ppm}$ of ozone. Similarly, total E. coli load reduction (>7 log cycles) was achieved at $40 \mathrm{ppm}$ of ozone exposure for 60 minutes. Therefore, the results indicate that the ozone efficacy against microorganisms in cassava starch was mainly dependent on the sample moisture content and to ozone concentration and exposure time. Moreover, it was observed that ozone is a promising technology to reduce microbial counts in dried food.
\end{abstract}

Keywords: ozonation; food processing; non-thermal technologies.

\section{Introduction}

Today's consumers have demanded processed products very similar to fresh food (TRIBST; SANT'ANA; DE MASSAGUER, 2009). For such reason, the development of non-thermal methods for food processing has been extensively studied - e.g. high-hydrostatic pressure, irradiation, UV radiation, pulsed electric field, pulsed light, ultrasound, and high-pressure homogenization, and ozone (DIELS; WUYTACK; MICHIELS, 2003; TRIBST; SANT'ANA; DE MASSAGUER, 2009; KLOCKOW; KEENER, 2009).

It is expected that products processed by such technologies maintain the nutrients and sensory characteristics better than thermal process. Among these technologies, ozone stands out for its antimicrobial properties and for being totally degradable in oxygen with no waste/toxic products (TIWARI et al., 2008, 2010); thus it is generally recognized as safe (GRAS) for food applications (GUZEL-SEYDIM; GREENE; SEYDIM, 2004; DHILLON et al., 2009; TIWARI et al., 2010). An additional advantage is the lower cost of ozone equipment (GUZELSEYDIM; GREENE; SEYDIM, 2004).

The ozone is a high oxidative compound with a broad antimicrobial spectrum; it is able to inactivate bacterial vegetative cells and spores, yeast, molds, and viruses and to kill insects in stored grains and degrade mycotoxins (TIWARI et al., 2010). Ozone inactivates microorganisms by the progressive oxidation of vital cellular components. The microbial surface is the primary target of ozonation with the oxidation of the polyunsaturated fatty acids and consequent loss of selective permeability and cell disruption. Additionally, ozone causes the oxidation of sulfhydryl groups and amino acids of enzymes, peptides, and proteins including nucleic acids and vital enzymes (KHADRE; YOUSEF; KIM, 2001; GUZEL-SEYDIM; GREENE; SEYDIM, 2004). In general, Gram negative bacteria are more sensitive to ozone treatment than Gram positive ones (KHADRE; YOUSEF; KIM, 2001). However, several other factors affect the ozone efficacy including the strain of the microorganism, age of the culture, density of the treated population, and presence of ozone-demanding medium components and method of applying ozone (KHADRE; YOUSEF; KIM, 2001)

In spores, ozone degrades the coat layer components thus exposing the cortex and the core to oxidation by ozone (KHADRE; YOUSEF, 2001; TIWARI et al., 2010). The molecular ozone and the reactive by-products of ozone decomposition (free radicals: $\mathrm{OH}^{-}, \mathrm{O}_{2}$ and $\mathrm{HO}_{3}^{-}$) have antimicrobial activity. Due to its high efficacy, low concentration and short contact time are normally enough to achieve the desired microbial inactivation.

Ozone has been previously used in food industry to inactivate microorganisms in packages and stainless steel surfaces (KHADRE; YOUSEF, 2001), for microbial decontamination of poultry carcasses, on chilled water treatment and recycling (GUZEL-SEYDIM; GREENE; SEYDIM, 2004; KHADRE; YOUSEF, 2001), for fish shelf-life extension (PASTORIZA et al., 2008), for fruit juice processing (TIWARI et al., 2009a, b), for sanitation of fruit and vegetables (ACHEN; YOUSEF, 2001; BIALKA; DEMIRCI, 2007; NAJAFI; KHODAPARAST, 2009; KIM; YOUSEF; CHISM, 1999; KOSEKI; ISOBE, 2006), and

\footnotetext{
Received 10/7/2012

Accepted 14/2/2013 (005780)

Department of Food Technology - DTA, School of Food Engineering - FEA, University of Campinas - UNICAMP, Rua Monteiro Lobato, 80, CP 6121,

Cidade Universitária Zeferino Vaz, CEP 13083-862, Campinas, SP, Brazil, e-mail: olecram@fea.unicamp.br

2 Technical School of Campinas - COTUCA, University of Campinas - UNICAMP, Campinas, SP, Brazil

*Corresponding author
} 
for decontamination of dry products as seeds, grains, and pepper (TIWARI et al., 2010, AKBAS; OZDEMIR, 2006; EMER; AKBAS; OZDEMIR, 2008; IBANOGLU, 2001, 2002; KETTERINGHAM et al., 2006; ZHAO; CRANSTON, 1995).

In addition to ozone antimicrobial potential, this gas can also be used to change physicochemical characteristics of corn, sago, and tapioca starch (CHAN; BHAT; KARIM, 2009) and wheat flour (LI et al., 2012) by oxidation improving their functional performance and presenting better results than those obtained by the traditional oxidation process (using chlorine).

Cassava starch is an important raw material in the food industry due its absence of "cereal flavor", typically observed in corn starch, its viscoamylographic standard during cooking (DEMIATE et al., 2005), its pasta low temperature, and its syneresis low susceptibility (SILVA et al., 2003).

Considering that cassava starch is extracted from plant root, it is potentially contaminated with many microorganisms, mainly bacterial spores. Therefore, some processes are required to guarantee the microbial stability of cassava starch before its use as raw material in the food industry. Due to low temperature gelation, the thermal process application for microbial inactivation of cassava starch is not feasible (CEREDA; VILPOUX, 2005); therefore, the development of a non-thermal process is necessary.

The Bacillus subtilis is considered an ideal target for the chemical process of microbial inactivation due to its safety and high resistance to chemical compounds (MOREAU; ORANGE; FEUILLOLEY, 2008). In addition to the analysis of the spore forming microorganisms, which are potentially starch pathogens or spoilers, the evaluation of Escherichia coli was carried out considering the the Brazilian food legislation (BRASIL, 2001), which establishes a maximum limit of coliforms able to growth at $45^{\circ} \mathrm{C}$ of $10^{2} \mathrm{CFU} / \mathrm{g}$ of starch.

Therefore, based on the ozone properties as a sanitizer and the requirements of a non-thermal process to stabilize cassava starch, this study aimed to evaluate the efficacy of ozone inactivation of B. subtilis spores and E. coli in cassava starch.

\section{Materials and methods}

\subsection{Starch and microorganisms}

Cassava starch was supplied by the company Corn Products Brasil (Conchal, Brazil). It was previously sterilized using $\gamma-$ irradiation (10 kGy) performed by the Brazilian Radiation company (EMBRARAD- Cotia, Brazil) to inactivate its native microorganisms.

The lyophilized strains of Bacillus subtilis ATCC 6633 and Escherichia coli ATCC 8739 were donated by André Tosello Research and Technology Foundation - FAT (Campinas, Brazil - www.fat.org.br).

\subsection{Cell culture suspensions}

The E. coli and B.subtilis cultures were activated using nutrient broth and kept under refrigeration on nutrient agar slants.
Petri dishes containing nutrient agar were inoculated with E. coli in and incubated at $37^{\circ} \mathrm{C}$ for 24 hours. To prepare E. coli suspension, the cell mass was harvested in sterile peptone water and used on the same day. The B. subtilis spores suspension was prepared as described by Wuytach, Boven and Michiels (1998), with few modifications: B. subtilis sporulation was carried out on nutrient agar supplement with $20 \mathrm{mg} . \mathrm{L}^{-1}$ of manganese sulphate, incubation was carried out at $30{ }^{\circ} \mathrm{C}$ for 14 days and, after harvesting, spores were three times centrifuged at 10,000 rpm for 10 minutes at $10{ }^{\circ} \mathrm{C}$. A heat shock at $70{ }^{\circ} \mathrm{C}$ for 20 min was carried out before B. subtilis count. Both microorganisms were plate counted on nutrient agar and incubated at $30{ }^{\circ} \mathrm{C}$ for 48 hours (B. subtilis) or $37^{\circ} \mathrm{C}$ for 24 hours (E. coli).

\subsection{Ozonation}

Ozone was produced from concentrated $\mathrm{O}_{2}$ air (Model NewLife Elite, AirSep Corporation, New York, United States) using an Interozone generator (Line DEVOC ${ }^{\oplus}$, Model SGOZ123, Interozone Group of Brazil, Jundiaí, Brazil) with $5 \mathrm{~g} \cdot \mathrm{h}^{-1}$ of production capacity. The ozonized air flow was $14 \mathrm{~m}^{3} \cdot \mathrm{h}^{-1}$, and the ozone concentration in the gas was continuously monitored by an ozone analyzer (Model UV-100, Eco Sensors, Inc., Santa $\mathrm{Fe}$, USA). Ozonized air was injected in a stainless steel powder mixer of $25 \mathrm{~L}$ through two air inlet devices located in the mixer lid. The spinning blades promoted an efficient contact between starch and ozonized air.

\subsection{Ozone treatment of cassava starch inoculated with E. coli}

$1 \mathrm{~kg}$ of cassava starch (initial moisture of 11\%) was inoculated with $100 \mathrm{~mL}$ of $E$. coli suspension reaching a final count of $10^{6}-10^{8} \mathrm{CFU} \cdot \mathrm{g}^{-1}$ and moisture of $18 \%$ (maximum limit of starch moisture allowed by the Brazilian law). For assays using cassava starch moisture at 30\% (moisture of starch immediately after cassava centrifugation carried out in the starch industry just before the drying processing), the samples were previously humidified with sterile water, followed by inoculation with $100 \mathrm{~mL}$ of $E$. coli suspension. After inoculation, cassava starch rested for one hour before ozonation to enable the adherence of microorganism to starch.

The starch of $18 \%$ moisture content was processed at ozone concentration of 40 and $113 \mathrm{mg} \cdot \mathrm{L}^{-1}$ for $30,60,90$, and 120 minutes. The starch of $30 \%$ moisture content was processed at ozone concentration of $40 \mathrm{mg} . \mathrm{L}^{-1}$ for $30,60,90$, and 120 minutes or at ozone concentration of $118 \mathrm{mg} . \mathrm{L}^{-1}$ for $15,30,45$, and 60 minutes. The 113 and $118 \mathrm{mg} \cdot \mathrm{L}^{-1}$ were the higher ozone levels reached in the equipment for the samples at 18 and $30 \%$ of moisture. This small variation in the maximum ozone concentration can be attributed to few oscillations in the oxygen concentration and ozone generated in the equipment.

Survivor counts of E. coli were performed on nutrient agar just after the ozonation process. The control samples were obtained by exposing previously inoculated cassava starch to air (without ozone) under the same conditions used for the ozonized samples. Initial count was determined by starch plating immediately after inoculation. The samples were incubated at 
$37^{\circ} \mathrm{C}$ for $24 \mathrm{~h}$. The Number of Decimal Reductions (NDR) of each process was determined according to Equation 1.

$\mathrm{NDR}=\log ($ initial count $)-\log ($ survivor's count $)$

\subsection{Ozone treatment of cassava starch inoculated with B. subtilis}

$1 \mathrm{~kg}$ of cassava starch was inoculated with $B$. subtilis spores suspension at the same conditions described for E. coli. B. subtilis final count was $10^{7} \mathrm{CFU} \cdot \mathrm{g}^{-1}$, and cassava starch moisture was 18 and $30 \%$. The inoculated sample was allowed to rest for 1 hour for the adherence of microorganism to starch, and the starch of $18 \%$ moisture content was then ozonized at ozone concentration of $118 \mathrm{mg} . \mathrm{L}^{-1}$ for $30,60,90$, and 120 minutes, and starch of $30 \%$ moisture content was processed at 40 and $118 \mathrm{mg} . \mathrm{L}^{-1}$ for 30,60 , 90 , and 120 minutes.

The B. subtilis enumeration was carried out after a heat shock $\left(70^{\circ} \mathrm{C} / 20\right.$ minutes) for spore activation. The samples were plated on nutrient agar and incubated at $30^{\circ} \mathrm{C}$ for 48 hours. The control samples were obtained by exposing previously inoculated cassava starch to air (without ozone) under the same conditions used for the ozonized samples. Initial count was determined by starch plating immediately after inoculation. The Number of Decimal Reductions (NDR) of each process was determined by Equation 1 .

\subsection{Statistical analysis}

The analysis of variance (ANOVA) was performed to compare the effects of the different treatments, and the Tukey test was used to determine their differences at a 5\% confidence level. Statistical analyses were carried out using STATISTICA 5.0 software (StatSoft, Inc., Tulsa, Okla.,U.S.A). All of the tested conditions were evaluated in triplicate. The results were presented as mean \pm standard deviation.

\section{Results and discussion}

\subsection{E. coli inactivation}

The E. coli inactivation on ozonized $18 \%$ moisture cassava starch is shown in Figure 1. Statistical analysis indicated that 30, 60 , and 90 minutes of contact time with $40 \mathrm{mg} \cdot \mathrm{L}^{-1}$ ozone caused about one decimal reduction, with no differences between

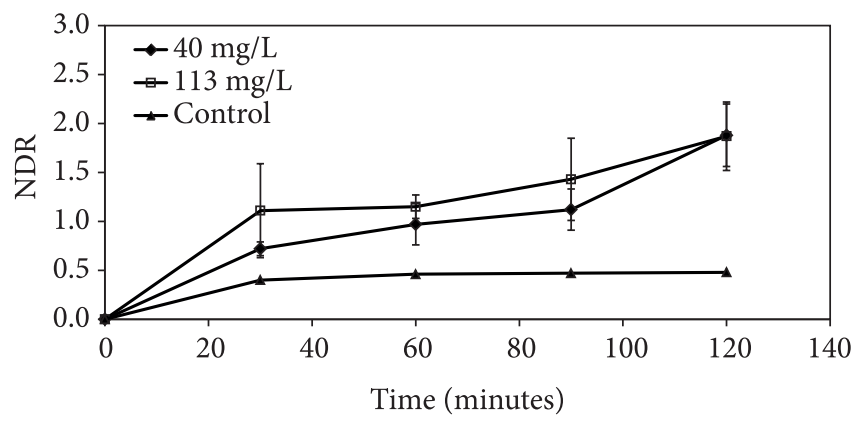

Figure 1. Inactivation of E. coli in ozonized $18 \%$ moisture cassava starch. Vertical bars represent the standard deviation of each value. them ( $p>0.05)$. On the other hand, 120 minutes of contact at this same concentration caused about 2 decimal reduction, and it was different from other conditions evaluated $(\mathrm{p}<0.05)$. The results of cassava starch ozonized at the concentration of 113 mg.L. ${ }^{-1}$ showed 1-2 decimal reduction, with no significant differences between different ozone contact times. Considering the control sample results $(<0.5 \mathrm{NDR})$, it was observed that ozone was able to reduce $E$. coli counts in $18 \%$ moisture cassava starch, but these reductions ( $<2$ decimal reductions) were not enough to guarantee the cassava starch safety when used as food raw material. Moreover, no significant differences were observed between E. coli inactivation in the samples ozonized at 40 and $113 \mathrm{mg} . \mathrm{L}^{-1}$, which probably indicates ozone saturation at concentration of $40 \mathrm{mg} \cdot \mathrm{L}^{-1}$.

The effect of starch humidification on the ozone efficacy was evaluated through ozonation process carried out on previously humidified starch at 30\% moisture (moisture of the starch after centrifugation). The E. coli inactivation at this condition is shown in Table 1.

The control treatment (carried out with no ozone injection) showed 1.3-1.6 decimal reductions, indicating that at 30\% moisture, the microorganism was more sensitive in non-ideal growth media or its recovery after the process was reduced. Comparing the results of control and ozonized samples, on the other hand, it was observed that ozonation was able to inactivate the microorganism.

The results showed that increases in ozone concentration and exposure time improve E. coli inactivation during the process. Processes applying ozone concentration at $40 \mathrm{mg} . \mathrm{L}^{-1}$ for 60 minutes or $118 \mathrm{mg} . \mathrm{L}^{-1}$ for 30 minutes are enough to guarantee an adequate level of $E$. coli inactivation assuring the safety of foods with this starch as raw material.

E. coli inactivation by ozone has been previously studied by several authors in different products including water, fruits, vegetables, meat, and dry products (MUTHUKUMARAPPAN; HALAWEISH; NAIDU, 2000; ZHAO; CRANSTON, 1995; KHADRE; YOUSEF; KIM, 2001; AKBAS; OZDEMIR, 2006, 2008b; EMER; AKBAS; OZDEMIR, 2008). These studies were carried out using different equipment and strains of $E$. coli, but, in general, it was observed that higher inactivation occurred in water or products with high moisture (MUTHUKUMARAPPAN; HALAWEISH; NAIDU, 2000).

The use of $0.35 \mathrm{ppm}$ of ozone resulted in 5 decimal reductions of $E$ coli in water, and the use of $18 \mathrm{ppm}$ for 50 minutes resulted in total load inactivation of $E$ coli O157:H7

Table 1. Inactivation of E. coli in ozonized 30\% moisture cassava starch.

\begin{tabular}{cccc}
\hline \multirow{2}{*}{$\begin{array}{c}\text { Time } \\
\text { (minutes) }\end{array}$} & \multicolumn{3}{c}{ NRD at different ozone concentration } \\
\cline { 2 - 4 }${ }^{\star} 0 \mathrm{mg} \cdot \mathrm{L}^{-1}$ & $40 \mathrm{mg} \cdot \mathrm{L}^{-1}$ & $118 \mathrm{mg} \cdot \mathrm{L}^{-1}$ \\
\hline 15 & - & - & 3.57 \\
30 & 1.26 & 3.72 & $>6$ \\
45 & - & - & $>7$ \\
60 & 1.45 & $>7$ & $>7$ \\
90 & 1.51 & $>7$ & - \\
120 & 1.64 & $>7$ & - \\
\hline
\end{tabular}

${ }^{*}$ Results of control sample. These values are the NDR average of two processes. 
in several foods (MUTHUKUMARAPPAN; HALAWEISH; NAIDU, 2000). The concentration of $1.0 \mathrm{ppm}$ of ozone applied for 360 minutes resulted in 3.5 decimal reduction in dried figs (AKBAS; OZDEMIR, 2008b). For pistachio (AKBAS; OZDEMIR, 2006), red pepper (AKBAS; OZDEMIR, 2008b), and black pepper (EMER; AKBAS; OZDEMIR, 2008), similar inactivation level (about 2 decimal reductions) was obtained after ozonation for 120-360 minutes.

Therefore, the presence of water in food is very important to reach high microbial inactivation level by ozone, as observed in the present study. Similarly, previous results showed that microbial inactivation by ozone on black pepper was improved at high moisture content (ZHAO; CRANSTON, 1995). It is known that ozone is a powerful oxidative compound that reacts with microorganism and organic materials (KHADRE; YOUSEF; KIM, 2001; MUTHUKUMARAPPAN; HALAWEISH; NAIDU, 2000). Thus, the increase in the organic material content may have affected the ozone efficacy.

Additionally, the ozone gas is rapidly decomposed in oxygen (MUTHUKUMARAPPAN; HALAWEISH; NAIDU, 2000). It is possible that ozone partial dissolution in the food free water results in the increase in the antimicrobial half-life, which can become more effective. Another possible effect is that moisture can improve the gas-product contact area or promote water freeradical formation that was effective for microbial inactivation in addition to the ozone effects.

Comparing the results obtained for E. coli inactivation in the cassava starch and other dry products (AKBAS; OZDEMIR, 2006, 2008b; EMER; AKBAS; OZDEMIR, 2008), it was observed that, for the other products, lower ozone concentration of $0.5-1 \mathrm{mg} \cdot \mathrm{L}^{-1}$ was required to reach the same level of inactivation (i.e., 40 times smaller than that required for cassava starch). Additionally to the differences in the moisture content and water activity of these foods and cassava starch, the differences between the results obtained can be explained by different ozonized air flow and the amount of product ozonized, which interfere in the ozone available amount and also on ozone mass/ product mass ratio. Moreover, the E. coli adherence in cassava starch for one hour before ozonation and the powder small dimension with rough surface can also affect ozone activity.

\subsection{B. subtilis inactivation}

Considering the results obtained for E. coli inactivation in ozonized $18 \%$ moisture cassava starch and the expected higher ozone resistance of B. subtilis, its inactivation in $18 \%$ moisture cassava starch was evaluated only at the ozone concentration of $118 \mathrm{mg} . \mathrm{L}^{-1}$ (which was the maximum ozone concentration reached in the ozonation equipment). No B. subtilis spore reduction was observed in cassava starch of $18 \%$ moisture content, even after ozonation at $118 \mathrm{mg} . \mathrm{L}^{-1}$ concentration for 120 minutes (data not shown). This indicates that, at this cassava starch moisture, ozone was not effective for B. subtilis inactivation.

Comparing the results obtained for B. subtilis and E. coli inactivation (113 mg. $\mathrm{L}^{-1}$ ozone concentration), it was confirmed that Bacillus spores are more resistant to ozone than E. coli, as previously described by Akbas and Ozdemir (2008a, b) and Muthukumarappan, Halaweish and Naidu (2000). This can be

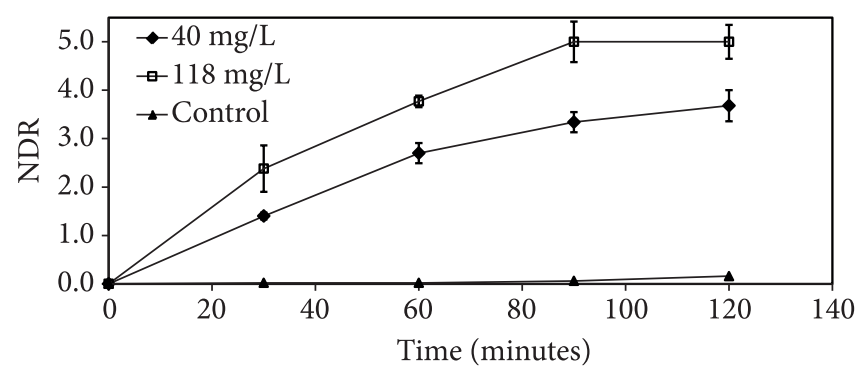

Figure 2. Inactivation of B. subtilis in ozonized 30\% moisture cassava starch. Vertical bars represent the standard deviation of each value.

explained by the high resistance of the spore coat and outer membrane to the oxidative mechanisms of the ozone (AKBAS; OZDEMIR, 2008a, b; MUTHUKUMARAPPAN; HALAWEISH; NAIDU, 2000), compared with oxidation of vegetative cell envelope and membrane.

The effect of $30 \%$ moisture starch on the ozone efficacy against $B$. subtilis was also evaluated, and the results are shown in Figure 2. The results showed that the control processes caused no significant reduction on B. subtilis spores. On the other hand ozone promoted B. subtilis spores inactivation at the concentration of 40 and $118 \mathrm{mg} . \mathrm{L}^{-1}$, and it was higher at higher ozone concentration $(\mathrm{p}<0.05)$. In addition, increased contact time up to 60 and 120 minutes caused a significant increase in spore inactivation at ozone concentration of 40 and $118 \mathrm{mg} . \mathrm{L}^{-1}$, respectively. Again, with the increase in the starch moisture, a significant increase in the microbial inactivation was observed. Data on B. subtilis spores in water also demonstrated higher level of spore inactivation, with $3 \log$ reductions after processing with $0.7 \mathrm{ppm}$ of ozone, indicating that the water content is important for spore inactivation.

It is interesting to highlight that by increasing ozone concentration by three times ( $40 \mathrm{mg} . \mathrm{L}^{-1}$ to $118 \mathrm{mg} . \mathrm{L}^{-1}$ ) it was able to reduce $50 \%$ of process time aiming to achieve the same level of B. subtilis spores inactivation, which can be a possible solution when low time processing is required.

Previous data on ozone treatment of wheat and wheat flour showed low level of inactivation of total aerobic microorganism and yeast and moulds ( $<1$ decimal reduction) using ozonated water at concentrations up to $16.5 \mathrm{ppm}$ (IBANOGLU, 2001, 2002; LI et al., 2012). These results corroborate the findings that food with low water content possible slows ozone reaction speed and therefore reduces the disinfection ability of the ozone gas.

\section{Conclusion}

The ozonation process can be effective for E.coli and B. subtilis inactivation in cassava starch, and it is highly dependent on starch moisture. At low starch moisture (18\%), the process was not enough to guarantee microbial inactivation; however, at $30 \%$ moisture starch, it was possible to reach $>5$ decimal reductions, ensuring safe products. $E$ coli were less resistant to ozone treatment, and it was inactivated after 30 minutes treatment with $118 \mathrm{ppm}$ of ozone. On the other hand, 90 minutes are required to reach an appropriated inactivation of B. subtilis. Therefore, the application of ozone at these conditions makes cassava starch a safe product to be used as a raw material in the food industry. 


\section{Acknowledgments}

The authors would like to thank the São Paulo Research Foundation (FAPESP) for financial support to the project \# 2008/10942-5, the Brazilian National Research Council (CNPq) for the E.O.C Amorim fellowship, and the Corn Products Brasil for the cassava starch donation.

\section{References}

ACHEN, M.; YOUSEF, A. E. Efficacy of ozone against Escherichia coli O157:H7 on apples. Journal of Food Science, v. 66, n. 9, p. 13801384, 2001. http://dx.doi.org/10.1111/j.1365-2621.2001.tb15218.x

AKBAS, M. Y.; OZDEMIR, M. Effectiveness of ozone for inactivation of Escherichia coli and Bacillus cereus in pistachios. International Journal of Food Science and Technology, v. 41, n. 5, p. 513-519, 2006. http://dx.doi.org/10.1111/j.1365-2621.2005.01099.x

AKBAS, M. Y.; OZDEMIR, M. Application of gaseous ozone to control populations of Escherichia coli, Bacillus cereus and Bacillus cereus spores in dried figs. Food Microbiology, v. 25, n. 2, p. 386-391, 2008a. http://dx.doi.org/10.1016/j.fm.2007.09.007

AKBAS, M. Y.; OZDEMIR, M. Effect of gaseous ozone on microbial inactivation and sensory of flaked red peppers. International Journal of Food Science and Technology, v. 43, n. 9, p. 1657-1662, 2008 b. http://dx.doi.org/10.1111/j.1365-2621.2008.01722.x

BIALKA, K. L.; DEMIRCI, A. Utilization of gaseous ozone for the decontamination of Escherichia coli O157:H7 and Salmonella on raspberries and strawberries. Journal of Food Protection, v. 70, n. 5, p. 1093-1098, 2007.

BRASIL. Ministério da Saúde. Resolução RDC n 12, de 02 de janeiro de 2001. Aprova o regulamento técnico sobre padrões microbiológicos para alimentos. Diário Oficial da República Federativa do Brasil, Brasília, DF, 10 jan. 2001.

CEREDA, M. P.; VILPOUX, O. Uso de lâmpada ultravioleta Germetec para redução de conteúdo microbiano de amido comercial de mandioca. Centro de Tecnologias para o Agro-negócio, Universidade Católica Dom Bosco, 2005. Nota prévia.

CHAN, H. T.; BHAT, R.; KARIM, A. A. Physicochemical and functional properties of ozone-oxidized starch. Journal of Agricultural and Food Chemistry, v. 57, p. 5965-5970, 2009. http://dx.doi. org/10.1021/jf9008789

DEMIATE, I. M. et al. Viscographic characteristics of chemically modified cassava starches assessed by RVA. Publitio UEPG - Ciências Exatas e da Terra, v. 11, n. 1, p. 7-17, 2005.

DHILLON, B. et al. Development and evaluation of an ozonated water system for antimicrobial treatment of durum wheat. Journal of Food Science, v. 74, n. 7, p. E396-403, 2009. http://dx.doi. org/10.1111/j.1750-3841.2009.01275.x

DIELS, A. M. J.; WUYTACK, E. Y.; MICHIELS, C. W. Modeling inactivation of Staphylococcus aureus and Yersinia enterocolitica by high-pressure homogenization at different temperatures. International Journal of Food Microbiology, v. 87, n. 1-2, p. 55-62, 2003. http://dx.doi.org/10.1016/S0168-1605(03)00050-3

EMER, Z.; AKBAS, M. Y.; OZDEMIR, M. Bactericidal activity of ozone against Escherichia coli in whole and ground black peppers. Journal of Food Protection, v. 71, n. 5, p. 914-917, 2008.

GUZEL-SEYDIM, Z. B.; GREENE, A. K.; SEYDIM, A. C. Use of ozone in the food industry. LWT - Food Science and Technology, v. 37, n. 4, p. 453-460, 2004.
IBANOGLU, S. Influence of tempering with ozonated water on the selected properties of wheat flour. Journal of Food Engineering, v. 48 , n. 4 , p. $345-350,2001$. http://dx.doi.org/10.1016/S02608774(00)00177-1

IBANOGLU, S. Wheat washing with ozonated water: effects on selected flour properties. International Journal of Food Science and Technology, v. 37, n. 5, p. 579-584, 2002. http://dx.doi. org/10.1046/j.1365-2621.2002.00593.x

KHADRE, M. A.; YOUSEF, A. E. Decontamination of a multilaminated aseptic food packaging material and stainless steel by ozone. Journal of Food Safety, v. 21, p. 1-13, 2001. http://dx.doi. org/10.1111/j.1745-4565.2001.tb00304.x

KHADRE, M. A.; YOUSEF, A. E.; KIM, J-G. Microbiological aspects of ozone applications in food: a review. Journal of Food Science, v. 66, n. 9, p. 1242-1252, 2001. http://dx.doi.org/10.1111/j.1365-2621.2001. tb15196.x

KETTERINGHAM, L. et al. Application of aqueous ozone for treating pre-cut green peppers (Capsicum annuum L.). Journal of Food Engineering, v. 76, p. 104-111, 2006. http://dx.doi.org/10.1016/j. jfoodeng.2005.05.019

KIM, J.-G.; YOUSEF, A. E.; CHISM, G. W.Use of ozone to inactivate microorganisms on lettuce. Journal of Food Safety, v. 19, p. 17-34, 1999. http://dx.doi.org/10.1111/j.1745-4565.1999. tb00231.x

KLOCKOW, P. A.; KEENER, K. M. Safety and quality assessment of packaged spinach treated with a novel ozone-generation system. LWT - Food Science and Technology, v. 42, n. 6, p. 1047-1053, 2009.

KOSEKI, S.; ISOBE, S. Effect of ozonated water treatment on microbial control and on browning of Iceberg Lettuce (Lactuca sativa L.). Journal of Food Protection, v. 69, n. 1, p. 154-160, 2006.

LI, M. et al. Evaluation the quality characteristics of wheat flour and shelf-life of fresh noodles as affected by ozone treatment. Food Chemistry, v. 135, p. 2163-2169, 2012. http://dx.doi.org/10.1016/j. foodchem.2012.06.103

MOREAU, M.; ORANGE, N.; FEUILLOLEY, M. G. J. Non-thermal plasma technologies: New tools for bio-decontamination. Biotechnology Advances, v. 26, n. 6, p. 610-617, 2008. http://dx.doi. org/10.1016/j.biotechadv.2008.08.001

MUTHUKUMARAPPAN, K.; HALAWEISH, F.; NAIDU, A. S. Ozone. In: NAIDU, A. S. Natural Food Antimicrobial Systems. CRC Press, 2000. http://dx.doi.org/10.1201/9781420039368.ch29

NAJAFI, M. B. H.; KHODAPARAST, M. H. H. Efficacy of ozone to reduce microbial populations in date fruits. Food Control, v. 20, p. 27-30, 2009. http://dx.doi.org/10.1016/j.foodcont.2008.01.010

PASTORIZA, L. et al. Use of sterile and ozonized water as a strategy to stabilize the quality of stored refrigerated fresh fish. Food Control, v. 19, p. 772-780, 2008. http://dx.doi.org/10.1016/j. foodcont.2007.08.003

SILVA, G. O. et al. Amidos nativos e modificados: propriedades e aplicações em alimentos. Boletim da Sociedade Brasileira de Ciência e Tecnologia de Alimentos, v. 37, p. 101-106, 2003. Suplemento.

TIWARI, B. K. et al. Effect of ozonation on the rheological and colour characteristics of hydrocolloid dispersions. Food Research International, v. 41, n. 10, p. 1035-1043, 2008. http://dx.doi. org/10.1016/j.foodres.2008.07.011

TIWARI, B. K. et al. Anthocyanin and colour degradation in ozone treated blackberry juice. Innovative Food Science and Emerging Technologies, v. 10, n. 1, p. 70-75, 2009a. http://dx.doi. org/10.1016/j.ifset.2008.08.002 
TIWARI, B. K. et al. Effect of ozone processing on anthocyanins and ascorbic acid degradation of strawberry juice. Food Chemistry, v. 113, n. 4, p. 1119-1126, 2009b. http://dx.doi.org/10.1016/j. foodchem.2008.08.085

TIWARI, B. K. et al. Review: Application of ozone in grain processing. Journal of Cereal Science, v. 51, p. 248-255, 2010. http://dx.doi. org/10.1016/j.jcs.2010.01.007

TRIBST, A A. L.; SANT’ANA, A. S.; DE MASSAGUER, P. R. Review: Microbiological quality and safety of fruit juices - past, present and future perspectives. Critical Reviews in Microbiology, v. 35 , n. 4 , p. $310-339,2009$. PMid:19863382. http://dx.doi. org/10.3109/10408410903241428

WUYTACH, E. Y.; BOVEN, S.; MICHIELS, C. W. Comparative Study of Pressure-Induced Germination of Bacillus subtilis Spores at Low and High Pressures. Applied and Environmental Microbiology, v. 64, n. 9, p. 3220-3224, 1998.

ZHAO, J.; CRANSTON, P. M. Microbial decontamination of black pepper by ozone and the effect of the treatment on volatile oil constituents of the spice. Journal of the Science of Food and Agriculture, v. 68, n. 1, p. 11-18, 1995. http://dx.doi.org/10.1002/ jsfa. 2740680103 